\title{
Photocatalytic decolorization of methylene blue using zinc oxide supported on mesoporous silica nanoparticles
}

\author{
Anis Farhana Abdul Rahman ${ }^{1}$, Ling Sy $\mathrm{Mei}^{1}$, Aishah Abdul Jalii ${ }^{1,2 *}$, Sugeng Triwahyono ${ }^{3,4}$ \\ ${ }^{l}$ Department of Chemical Engineering, Faculty of Chemical and Energy Engineering, Universiti Teknologi Malaysia, 81310 UTM Johor Bahru, Johor, \\ Malaysia \\ ${ }^{2}$ Centre of Hydrogen Energy, Institute of Future Energy, Universiti Teknologi Malaysia, 81310 UTM Johor Bahru, Johor, Malaysia \\ ${ }^{3}$ Department of Chemistry, Faculty of Science, Universiti Teknologi Malaysia, 81310 UTM Johor Bahru, Johor, Malaysia. \\ ${ }^{4}$ Centre of Sustainable Nanomaterials, Ibnu Sina Institute for Scientific and Industrial Research, Universiti Teknologi Malaysia, 81310 UTM Johor Bahru, \\ Johor, Malaysia.
}

*Corresponding Author: aishahaj@utm.my

Article history :

Received 23 November 2015

Accepted 15 December 2015

\section{GRAPHICAL ABSTRACT}

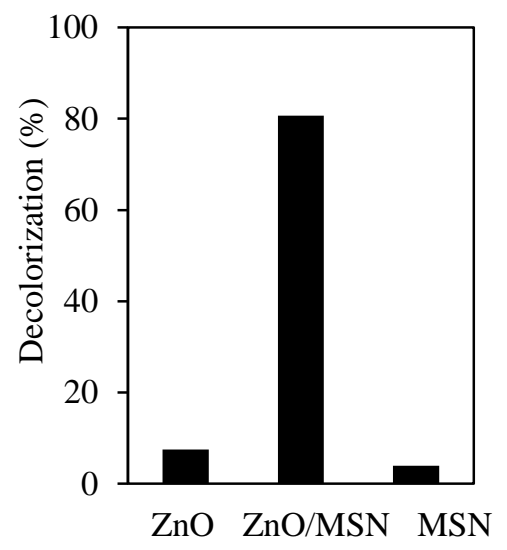

\begin{abstract}
Various dyes that are used in textile, paper, cosmetics and plastics industries may produce harmful effects on the health of living organisms and the environment if not treated properly before being discharged into water bodies. Among many techniques, photocatalytic process is one of the promising treatment for these dyes. Zinc oxide $(\mathrm{ZnO})$ is well-known comparable with $\mathrm{TiO}_{2}$ due to its unique properties and numerous advantages. While, mesoporous silica nanoparticles (MSN) is an excellent solid support for heterogeneous catalysts due to its high surface area, thermal and mechanical stability, highly uniform pore distribution, tunable pore size, and unique hosting properties. Therefore, in this study, ZnO/MSN (ZM) catalysts were prepared and its physicochemical properties was characterized by X-Ray Diffraction (XRD) and Fourier Transform Infrared Spectroscopy (FTIR). The catalyst was tested on the photodecolorization of methylene blue (MB) dye. The results showed that the interaction between $\mathrm{ZnO}$ and MSN support could enhanced the photocatalytic activity. The $0.5 \mathrm{~g} \mathrm{~L}^{-1}$ of $5 \mathrm{ZM}$ was found to give the highest degradation ( $80 \%$ ) of $10 \mathrm{mg} \mathrm{L}^{-1}$ of MB solution at $\mathrm{pH} 7$ after $3 \mathrm{~h}$ under UV light irradiation. The photodecolorization followed the pseudo first-order Langmuir-Hinshelwood kinetic model. This study demonstrated that the prepared 5ZM has a potential to be used in photocatalytic degradation of various dyes as well as organic pollutants.
\end{abstract}

Keywords: $\mathrm{ZnO}$, MSN, electrochemical, photocatalysis, methylene blue

(C) 2015 Penerbit UTM Press. All rights reserved http://dx.doi.org/10.11113/mjfas.v11n4.397

\section{INTRODUCTION}

In recent years, dyes widely used in the textile, paper, cosmetics and plastics industries have led to severe environmental contamination due to the emission of toxic and colored wastewater into water bodies [1-3]. It was found that over 100,000 dyes are commercially available and more than $7 \times 10^{5}$ tonnes per year are produced annually [4]. Organic dyes are generally present in the industrial wastewater and cannot be readily degraded because of their stable chemical structures. The discharged of these dyes into water bodies can cause severe problem because of their toxicity, mutagenic and carcinogenic [5-7]. Therefore, many treatment technologies widely used, such as adsorption, coagulation, flocculation, ion exchange and membrane separation [8]. However, these treatments are usually reported as inefficient methods and produce secondary products [9].

Advanced oxidation process (AOP) using heterogeneous semiconductors such as $\mathrm{TiO}_{2}, \mathrm{ZnO}, \mathrm{WO}_{3}$,
$\mathrm{Fe}_{2} \mathrm{O}_{3}, \mathrm{CuO}, \mathrm{ZrO}_{2}$, and $\mathrm{CdS}$ as photocatalysts are efficient technique in wastewater treatment because it has capability to convert harmful dyes into non-toxic products, $\mathrm{CO}_{2}$ and water at ambient temperatures [10,11]. Among them, $\mathrm{ZnO}$ is an excellent candidate for applications as photocatalyst because of its unique properties and numerous advantages, such as high photosensitivity and stability in degrading various toxic substances [12]. Even though $\mathrm{ZnO}$ has sufficient photocatalytic activity, its poor adsorption properties lead to inefficient photocatalytic activity. Thus, to overcome this shortcoming, an appropriate method need to be exploited in order to improve the adsorption properties of $\mathrm{ZnO}$. Incorporation of $\mathrm{ZnO}$ into a mesoporous material support is one of the promising methods which have been discussed by several researchers in recent years $[13,14]$. The objective of this study after considering all the factors is to synthesize $\mathrm{ZnO} / \mathrm{MSN}$ catalysts and study its performance on photocatalytic decolorization of methylene blue (MB). 


\section{EXPERIMENTS}

\subsection{Catalyst Preparation}

All of the chemical reagents were purchased and used as received without further purification. $\mathrm{ZM}$ catalysts were prepared using electrochemical method as reported in previous study [15-19]. Distilled water and $\mathrm{NH}_{4} \mathrm{OH}$ were added into TEAP and after electrolysis, MSN was added to the mixture. The mixture was then impregnated and dried before being calcined at $823 \mathrm{~K}$ for $3 \mathrm{~h}$.

\subsection{Characterization}

The crystalline structure of the catalyst was determined with $\mathrm{X}$-ray diffraction (XRD) recorded on a powder diffractometer (Bruker Advance D8, $40 \mathrm{kV}, 40$ $\mathrm{mA}$ ) using a $\mathrm{Cu} \mathrm{K} \alpha$ radiation source in the range of $2 \theta=$ 1.5-90 . FT-IR was performed using the $\mathrm{KBr}$ method with range of 400-4000 $\mathrm{cm}^{-1}$.

\subsection{Photocatalytic testing}

The photoactivities of the catalysts were evaluated for the decolorization of MB dye. The photocatalytic activity was performed in a batch reactor fixed with visible lamp and a cooling system. A $0.125 \mathrm{~g} \mathrm{L-1}$ catalyst was added to $200 \mathrm{~mL} \mathrm{MB}$ solution with a desired concentration and stirred for $1 \mathrm{~h}$ in the dark to achieve adsorptiondesorption equilibrium before being exposed to light radiation for $3 \mathrm{~h}$.

\section{RESULTS AND DISCUSSION}

\subsection{Physicochemical properties of the prepared catalyst}

Fig. 1A illustrates a wide-angle XRD pattern of pure $\mathrm{ZnO}$. A series of characteristic peaks were observed at $31.77^{\circ}$ (100), 34.42 ${ }^{\circ}(002), 36.52^{\circ}(101), 47.54^{\circ}$ (102), 56.60 $(110), 62.86^{\circ}(103), 66.38^{\circ}(200), 67.96^{\circ}(112)$ and $69.10^{\circ}$ (201), which can be indexed as a wurtzite phase of $\mathrm{ZnO}$ (JCPDS No. 36-1451). The diffraction peaks from other phases of $\mathrm{ZnO}$ and impurities could not be observed, suggesting that high-purity of $\mathrm{ZnO}$ was obtained [1]. The introducing of $\mathrm{ZnO}$ into MSN was also being studied using low-angle XRD pattern in the range of $2 \theta=1.5-10^{\circ}$ (Fig. 1B). Three diffraction peaks were observed at $2 \theta=2.39^{\circ}$, $4.05^{\circ}$, and $4.71^{\circ}$, relative to the (100), (110) and (200) reflections, respectively and these peaks represent typical mesostructured silica with hexagonally p6 mm symmetry structure formed by the 2D hexagonal arrays of the mesostructure [19]. Fig. 2 shows the FT-IR spectra of $\mathrm{ZnO}, \mathrm{MSN}$ and $5 \mathrm{ZM}$ catalysts in the region between 4000 and $400 \mathrm{~cm}^{-1}$. Three bands were observed at 466, 810 and $1095 \mathrm{~cm}^{-1}$ attributed to the bending vibrations, symmetric stretching and asymmetric stretching of $\mathrm{Si}-\mathrm{O}-\mathrm{Si}$ bonds in MSN, respectively. The band at $975 \mathrm{~cm}^{-1}$ was ascribed to
Si-OH bending vibrations in MSN. The intensity of all these bands increased when increase $\mathrm{ZnO}$ loading, which suggested a possible interaction of $\mathrm{Zn}$ on silica framework. Moreover, the intensity of band $975 \mathrm{~cm}^{-1}$ was decreased, indicating the replacement of the $-\mathrm{OH}$ group by $\mathrm{O}$-metal ions probably occurred. A broad band at $3471 \mathrm{~cm}^{-1}$ was observed for all samples, attributed to adsorb $\mathrm{H}_{2} \mathrm{O}$ molecules and bands at $1658 \mathrm{~cm}^{-1}$ which ascribed to water molecules retained by siliceous materials [20].
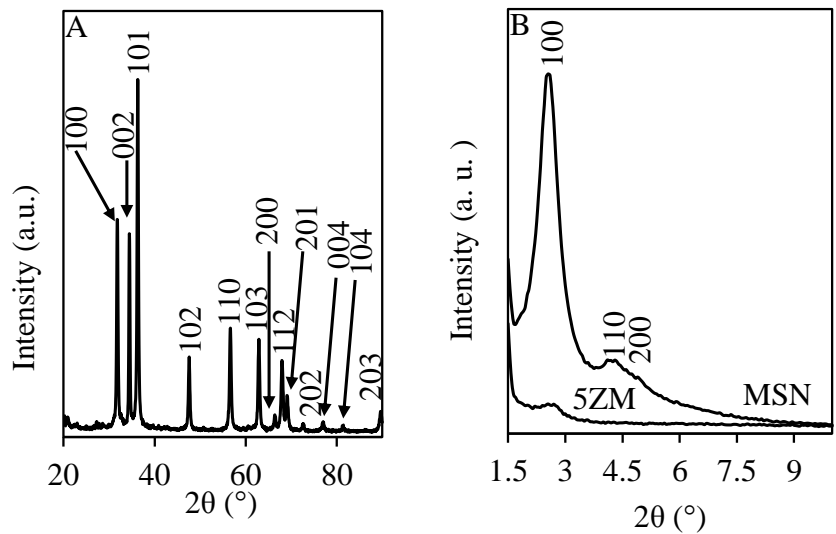

Fig. 1 (A) Wide-angle XRD patterns of $\mathrm{ZnO}$ and (B) small-angle XRD patterns

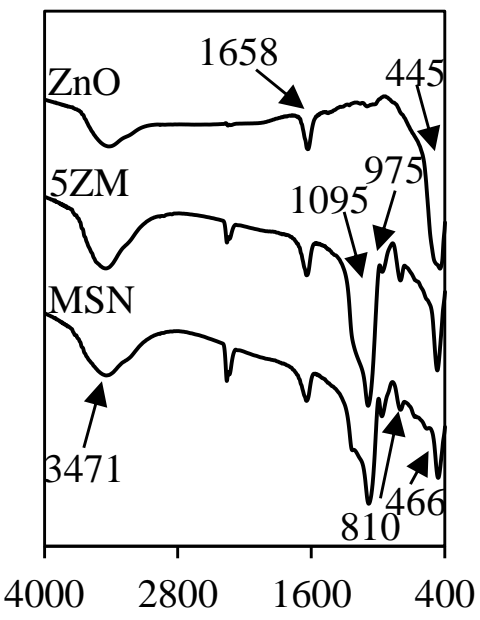

Fig 2 FTIR spectra of the catalysts

3.2 Photocatalytic testing on the decolorization of methylene blue

\subsubsection{Performance of the prepared catalyst}

The performances of $\mathrm{ZnO}, \mathrm{MSN}$ and $5 \mathrm{ZM}$ catalysts for the decolorization of methylene blue (MB) were examined, and the results are shown in Fig. 3. All catalysts were stirred for $1 \mathrm{~h}$ in the dark to achieve adsorption- 
desorption equilibrium before being exposed to visible light radiation for $3 \mathrm{~h}$.

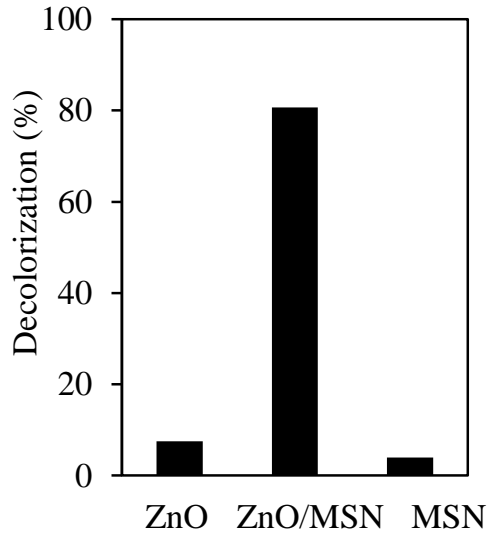

Fig. 3 Catalytic performance of the catalysts

No obvious photodecolorization was observed in the presence of bare MSN. Compared with pure $\mathrm{ZnO}$, the addition of $\mathrm{ZnO}$ into $\mathrm{MSN}$ resulted a higher decolorization percentage of MB $(80 \%)$. This result verified the role of MSN as a support to provide a good dispersion of active site, which led to a faster rate of reaction [21].

\subsubsection{Effect of $\mathrm{pH}$ and catalyst dosage}

The $\mathrm{pH}$ solution is one of the significant parameters that influence the rate of photocatalytic activity. In this study, the effect of $\mathrm{pH}$ on decolorization of $\mathrm{MB}$ by $5 \mathrm{ZM}$ was investigated by varying the $\mathrm{pH}$ values from 3 to 11 , and the results are presented in Fig. 4. The greatest decolorization was obtained at $\mathrm{pH} 7$, with 80 probably due to the neutral condition of the solution which in this $\mathrm{pH}$, more reaction between dye molecules and photocatalyst [1].

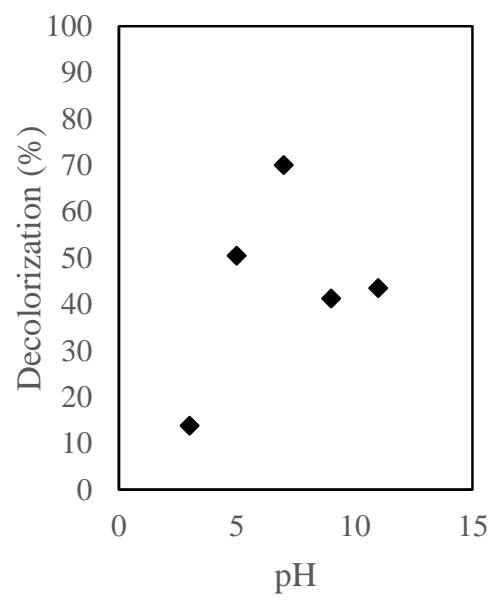

Fig. 4 Effect of $\mathrm{pH}$ on decolorization of $\mathrm{MB}$
The effect of 5ZM catalyst dosage was also studied in the range of $0.125-0.750 \mathrm{~g} \mathrm{~L}^{-1}$ and the results are shown in Fig. 5. The decolorization of $\mathrm{MB}$ increased with increasing catalyst dosage up to $0.5 \mathrm{~g} \mathrm{~L}^{-1}$, but further addition of the catalyst seemed to reduce the decolorization. This result could be due to the increase in the number of active sites that could absorb more photons and MB [1]. However, an excess dosage led to the turbidity of the suspension, which reduced the light penetration and inhibits photodecolorization [8].

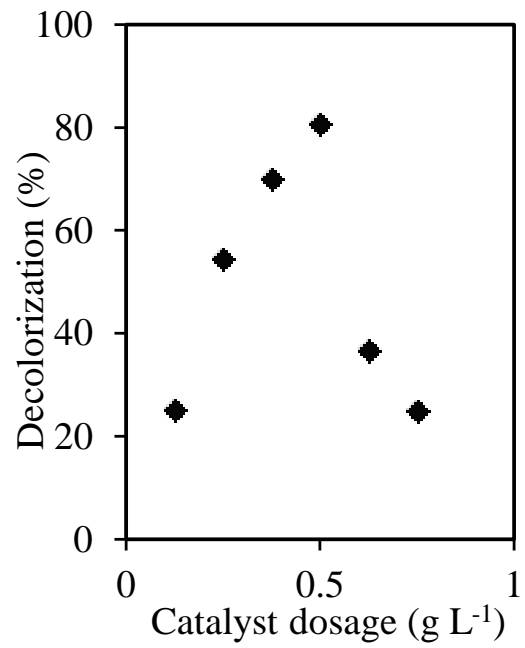

Fig. 5 Effect of catalyst dosage on decolorization of MB

\subsubsection{Kinetic studies}

Herein, the decolorization rates of MB were also studied using the Langmuir-Hinshelwood (L-H) model [2] over 5ZM catalyst and the linear plot of $\ln \left(\mathrm{C}_{0} / \mathrm{C}_{\mathrm{t}}\right)$ vs. irradiation time are shown in Fig. 6.

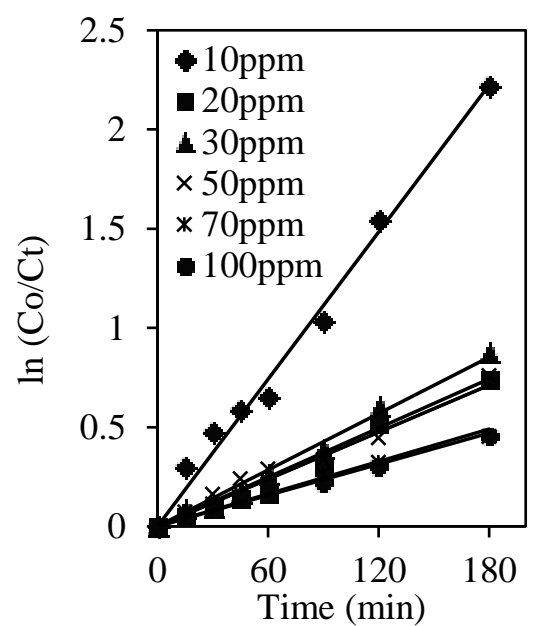

Fig.6 Photodecolorization kinetics of MB using different catalysts

A linear relation was obtained, which indicated that decolorization of $\mathrm{MB}$ by $\mathrm{ZM}$ followed Langmuir- 
Hinshelwood model. The calculated values of $k_{r}$ and $K_{L H}$ were $0.3413 \mathrm{mg} \mathrm{L}^{-1} \mathrm{~min}^{-1}$ and $0.0028 \mathrm{~L} \mathrm{mg-1}$, respectively. The values of $k_{r}$ was greater than $K_{L H}$, indicated that a surface reaction, where the dyes were absorbed, was the controlling step of the process [2].

\section{CONCLUSION}

In conclusion, 5ZM catalyst was prepared via electrochemical method. The physicochemical properties of the prepared catalyst were analyzed using XRD and FT-IR analysis. The results demonstrated that the introduction of $\mathrm{ZnO}$ into MSN maintains the structure of MSN and high purity of catalyst. $0.5 \mathrm{~g} \mathrm{~L}^{-1}$ catalyst was found to give the optimum loading, which resulted in $80 \%$ decolorization of $\mathrm{MB}$ at $\mathrm{pH} 7$ after $3 \mathrm{~h}$ of contact time under visible light irradiation. The kinetics studies showed that the decolorization process followed pseudo first-order and the rate constants determined using Langmuir-Hinsherlwood model were $\mathrm{k}_{\mathrm{r}}=0.3413 \mathrm{mg} \mathrm{L}-1 \min ^{-1}$ and $\mathrm{K}_{\mathrm{LH}}=0.0028 \mathrm{~L}$ $\mathrm{mg}^{-1}$. The value of $\mathrm{k}_{\mathrm{r}}$ is greater than $\mathrm{K}_{\mathrm{LH}}$, indicating that dye adsorption was the controlling step of the process. With the simple process of catalyst synthesizing and the low amount of metal loading required, this system exhibits great potential for improving the quality of wastewater discharged from industries.

\section{ACKNOWLEDGEMENTS}

This work was supported by Research University Grant form Universiti Teknologi Malaysia (4F423) and MyMaster Scholarship (A.F.A. Rahman) from Ministry of Higher Education, Malaysia.

\section{REFERENCES}

[1] N.W.C. Jusoh, A.A. Jalil, S. Triwahyono, H.D. Setiabudi, N. Sapawe, M.A.H. Satar, A.H. Karim, N.H.N. Kamarudin, R. Jusoh, N.F. Jaafar, N. Salamun, J. Efendi. Appl. Catal- A: Gen. 468 (2013) 276.

[2] A.A. Jalil, M.A.H. Satar, S. Triwahyono, H.D. Setiabudi, N.H.N. Kamarudin, N.F. Jaafar, N. Sapawe, R. Ahamad. J. Electroanal Chem. 701 (2013) 50.

[3] A.A. Jalil, S. Triwahyono, N. Sapawe, I.H. Ahmed, M.A.A. Aziz. Desalin Water Treat. (2015).

[4] C.I. Pearce, J.R. Lloyd, J.T. Dyes Pigments. 58 (2003): 179.

[5] E. Brillas, C.A. Martinez-Huitle. Appl. Catal. B: Environ. 166 (2015): 603.

[6] A.H. Karim, A.A. Jalil, S. Triwahyono, S.M. Sidik, N.H.N. Kamarudin, R. Jusoh, N.W.C. Jusoh, B.H. Hameed. J. Colloid. Interf. Sci. 386 (2012): 302

[7] A.H. Karim, A.A. Jalil, S. Triwahyono, N.H.N. Kamarudin, A. Ripin. J. Colloid. Interf. Sci. 421 (2014): 93

[8] N.F. Jaafar, A.A. Jalil, S. Triwahyono, N. Shamsuddin. RSC Adv. 5 (2015): 90991.

[9] H. Lachheb, E. Puzenat, A. Houas, M. Ksibi, E. Elaloui, C. Guillard, J.M. Herrmann. Appl. Catal B: Environ. 39 (2002): 75.

[10] U.I. Gaya, A.H. Abdullah. J. Photochem Photobio C. 9 (2008): 1.

[11] A. Houas, H. Lachheb, M. Ksibi, E. Elaloui, C. Guillard, J.M. Herrmann. Appl Catal B: Environ. 31 (2001): 145.

[12] S. Sakthivel, B. Neppolian, M.V. Shankar, B. Arabindoo, M. Palanichamy, V. Murugesan. Sol. Energ. Mat. Sol. C. 77 (2003): 65.

[13] C. Bouvy, W. Marine. B.L. Su. Chem. Phys. Lett. 438 (2007): 67.

[14] L.I. Burova, D.I. Petukhov, A.A. Eliseev, A.V. Lukashin, Y.D Tretyakov. Superlattice. Microst. 39 (2006): 25.

[15] A.A. Jalil, N. Kurono, M. Tokuda. Synlett 12 (2001): 1944

[16] A.A. Jalil, N. Kurono, M. Tokuda. Tetrahedron. 58 (2002): 7477

[17] A.A. Jalil, N. Kurono, M. Tokuda. Synthesis 18 (2002): 2681

[18] A.A. Jalil, N. Kurono, S. Tagasugi, M. Tokuda. J. IEM. 66 (2005):

[19] N.B. Lihitkar, M.K. Abyaneh, V. Samuel, R. Pasricha, S.W. Gosavi, S.K. Kulkarni. J. Colloid. Interf. Sci. 314 (2007): 310.

[20] D.R. Sahu, L.Y. Hong, S.C. Wang, J.L. Huang. Micropor. Mesopor Mat. 117 (2009): 640.

[21] R. Jusoh, A.A. Jalil, S. Triwahyono, A. Idris, M.Y. Noordin. Sep. Purif. Technol. 149 (2015): 55 